\title{
Detection of HSV-1 DNA in patients with Behçet's syndrome and in patients with recurrent oral ulcers by the polymerase chain reaction
}

\author{
M. STUDD, D. J. MCCANCE* and T. LEHNER
}

Department of Immunology, United Medical and Dental Schools of Guy's and St Thomas's Hospitals, London and "Department of Microbiology and Immunology, University of Rochester Medical Centre, 601 Elmwood Avenue, Box 672, Rochester, NY14642, USA

\begin{abstract}
Summary. The polymerase chain reaction was used to detect HSV-1 DNA in genomic DNA extracted from peripheral blood leucocytes, in patients with Behçet's syndrome (BS), patients with recurrent oral ulcers and normal healthy controls. A 211-bp HSV-1 DNA fragment was found in a significant number of patients with BS $(p<0.02)$. Serum anti-HSV-1 antibodies were also found in a higher proportion of patients with $B S(p<0.02)$ than in healthy controls. However, virus-specific DNA was not detected in biopsy samples taken from oral ulcers in patients with BS.
\end{abstract}

\section{Introduction}

Behçet's syndrome (BS) is a multi-system inflammatory disease, characterised by oral and genital ulceration and various cutaneous, arthritic, ocular, vascular and neurological manifestations. ${ }^{1}$ A viral aetiology has long been postulated for the disease. ${ }^{2}$ Inclusion bodies have been found in scrapings from ulcers ${ }^{3}$ and in biopsies, ${ }^{4,5}$ and an unidentified virus has been isolated from patients with BS by some workers, ${ }^{6,8}$ but not by others. ${ }^{9-11}$

However, there is indirect and direct evidence for the involvement of herpes simplex virus type 1 (HSV1) in BS. Thus, phytohaemagglutinin (PHA)-stimulated peripheral blood lymphocytes from patients with BS, unlike those from normal subjects, are unable to support the growth of HSV-1 ${ }^{12,13}$ and produce higher than normal amounts of interferon (IFN) $\gamma .{ }^{14}$ CD4 and $\mathrm{CD} 8$ cells from $\mathrm{BS}$ patients have been reported to have an impaired proliferative response to HSV-1, ${ }^{15}$ and increased levels of HSV-1 specific immune complexes have been found in serum. ${ }^{16}$

Examination of circulating lymphocytes, by in-situ hybridisation, has also revealed HSV-homologous RNA in patients with BS. ${ }^{17}$ This was confirmed by the demonstration of HSV-1-homologous DNA by the dot blot technique. ${ }^{18}$ We report here application of the polymerase chain reaction (PCR) to detect HSV-1 DNA sequences in DNA extracted from peripheral blood mononuclear cells from patients with BS and from control subjects, and in DNA extracted from biopsy samples from oral ulcers. The results are analysed by comparison with the serum anti-HSV-1 antibody level.

Received 30 May 1990; accepted 16 July 1990.

\section{Subjects and methods}

\section{Patients and controls}

Ninety-six patients and controls were investigated. Thirty-two patients with BS were diagnosed clinically ${ }^{1}$ as mucocutaneous type (2), arthritic type (12), ocular type (12) and neurological type (6) (table I). Three ageand sex-matched control groups included normal healthy subjects without a history of recurrent herpetic infection (22), patients with recurrent herpes labialis (12), and patients with recurrent oral ulcers (30). The latter were diagnosed ${ }^{19}$ as minor aphthous ulcers (11), major aphthous ulcers (10), and herpetiform ulcers (9).

Peripheral blood mononuclear cells were separated from heparinised blood samples by centrifugation on Ficoll/Isopaque, washed in phosphate-buffered saline (PBS) and stored as cell pellets at $-20^{\circ} \mathrm{C}$ until required for DNA extraction. Serum or plasma samples were stored at $-20^{\circ} \mathrm{C}$ until assayed for antibodies to HSV1 by solid phase radioimmunoassay. Biopsy samples of oral lesions were taken from 21 patients- 11 from patients with recurrent oral ulcers, three from BS patients and seven from patients with miscellaneous oral diseases. The biopsy samples were stored at $-70^{\circ} \mathrm{C}$ in Optimal Cutting Temperature (OCT) embedding compound (Miles Laboratories, Slough) and then examined by PCR.

\section{Preparation of DNA samples}

Cell pellets and finely chopped biopsy samples were thawed out into 5-10 ml of a buffer solution consisting of $10 \mathrm{~mm}$ Tris, pH 8.0, $10 \mathrm{~mm}$ EDTA, pH 8.0, $10 \mathrm{~mm}$ $\mathrm{NaCl}$ and SDS $0.5 \%$, and incubated with proteinase $\mathrm{K} 100 \mu \mathrm{g} / \mathrm{ml}$ (Boerhinger Corp. London, Ltd) (BCL) 
Table I. Clinical Manifestations of 32 patients with BS

\begin{tabular}{|c|c|c|c|c|c|c|c|c|c|c|}
\hline \multirow[b]{2}{*}{$\begin{array}{c}\text { Clinical } \\
\text { type of BS }\end{array}$} & \multirow[b]{2}{*}{$\begin{array}{c}\text { Number of } \\
\text { patients }\end{array}$} & \multirow[b]{2}{*}{ Sex } & \multirow[b]{2}{*}{ Age (y) } & \multicolumn{7}{|c|}{ Number of patients with } \\
\hline & & & & $\begin{array}{c}\text { oral } \\
\text { ulcers }\end{array}$ & $\begin{array}{l}\text { genital } \\
\text { ulcers }\end{array}$ & $\begin{array}{l}\text { skin } \\
\text { lesions }\end{array}$ & $\begin{array}{c}\text { arthralgia } \\
\text { or joint } \\
\text { swelling }\end{array}$ & $\begin{array}{c}\text { eye } \\
\text { lesions }\end{array}$ & $\begin{array}{l}\text { CNS } \\
\text { lesions }\end{array}$ & $\begin{array}{l}\text { vascular } \\
\text { lesions }\end{array}$ \\
\hline Mucocutaneous & 2 & $\mathbf{F}$ & $41-60$ & 2 & 2 & 1 & 0 & 0 & 0 & 0 \\
\hline Arthritic & 12 & $9 \mathrm{~F}, 3 \mathrm{M}$ & $29-55$ & 12 & 12 & 8 & 12 & 0 & 0 & 2 \\
\hline Ocular & 12 & $5 \mathrm{~F}, 7 \mathrm{M}$ & $24-50$ & 12 & 9 & 6 & 5 & 12 & 0 & 2 \\
\hline Neurological & 6 & $1 F, 5 M$ & $30-52$ & 6 & 5 & 5 & 1 & 2 & 6 & 3 \\
\hline
\end{tabular}

for several hours at $37^{\circ} \mathrm{C}$. After phenol-chloroform extraction, the DNA solution was reincubated at $37^{\circ} \mathrm{C}$ for $15 \mathrm{~min}$ with RNAase $50 \mu \mathrm{g} / \mathrm{ml}$ (BCL) and then for a further $30 \mathrm{~min}$ with proteinase $\mathrm{K} 100 \mu \mathrm{g} / \mathrm{ml}$ and SDS $1 \%$. The solution was re-extracted with phenolchloroform, and dialysed against a buffer solution of

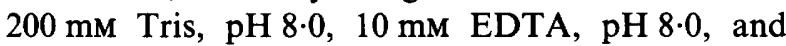
$10 \mathrm{mM} \mathrm{NaCl}$, until the $\mathrm{OD}_{270}$ of the dialysis buffer was $<0.05$. The DNA was precipitated by the addition of 0.1 volumes of $5 \mathrm{M}$ ammonium acetate and one volume of ice-cold isopropanol and overnight incubation at $-20^{\circ} \mathrm{C}$. The precipitate was redissolved in a solution of $10 \mathrm{~mm}$ Tris, pH 7.5, and $1 \mathrm{~mm}$ EDTA, and the concentration and purity were determined by measuring the $\mathrm{OD}_{260}$ and $\mathrm{OD}_{280}$.

\section{Polymerase chain reaction}

Oligonucleotide primers specific to sequences bordering a 211-bp region of the EcoR $1 \mathrm{~g}$ fragment of HSV-1 DNA, ${ }^{20}$ including two restriction sites for HpaII and a single site for Taq1, were purchased from Oswel DNA Service, Edinburgh University. The reactions were performed by a modification of the method of Saiki et al., ${ }^{21}$ in $100 \mu$ of a reaction buffer consisting of $67 \mathrm{mM}$ Tris, pH 8.8 at $25^{\circ} \mathrm{C}, 16.6 \mathrm{mM}$ ammonium sulphate, $10 \mathrm{mM}$ 2-mercaptoethanol, $3.2 \mathrm{mM}$ magnesium chloride, bovine serum albumin (BSA) $170 \mu \mathrm{g} / \mathrm{ml}, 200 \mu \mathrm{M}$ of each dNTP, $1 \mu \mathrm{M}$ of each primer, $1 \mu \mathrm{g}$ of template DNA previously denatured by boiling and cooling on ice, and 2.5 units of AmpliTaq ${ }^{\circledR}$ (Perkin Elmer Cetus).

In some experiments, all the reactants except the template DNA were pre-incubated $\left(37^{\circ} \mathrm{C}\right.$ for $1 \mathrm{~h}$, and then $75^{\circ} \mathrm{C}$ for $15 \mathrm{~min}$ ) with the restriction endonuclease $H$ paII to remove any contaminating template which could lead to false positive results. Reaction mixtures were subjected to 20,30 or 40 cycles of amplification on a Bio-excellence thermal cycler (Anglian Biotech). Each cycle consisted of $2 \mathrm{~min}$ at $94^{\circ} \mathrm{C}, 1 \mathrm{~min}$ at $60^{\circ} \mathrm{C}$ and 2 or $5 \mathrm{~min}$ at $72^{\circ} \mathrm{C} ; 2.5$ units of AmpliTaq were added to each reaction before cycling, and again after 20 cycles; $10-\mu$ l samples of amplified product were removed for analysis after 20 , 30 and 40 cycles.

\section{Analysis of PCR products}

The 10- $\mu$ l samples of amplified product were separated by electrophoresis on agarose $2 \%$ gels, containing ethidium bromide $1 \mu \mathrm{g} / \mathrm{ml}$, and visualised under UV light. Gels were alkali blotted (0.4 M NaOH) on to nylon membranes (Biodyne B, Pall Europe), rinsed in $2 \times \mathrm{SSC}(20 \times \mathrm{SSC}$ is a solution of $3 \mathrm{M}$ sodium chloride, and $0.3 \mathrm{M}$ sodium citrate) and air dried. Prehybridisation was performed at $68^{\circ} \mathrm{C}$ for several hours or overnight in a solution consisting of $5 \times \mathrm{SSC}, 5 \times$ Denhardts $(100 \times$ Denhardts is polyvinyl pyrrolidone $2 \%$, Ficoll $2 \%$ and BSA $2 \%$, SDS $0 \cdot 1 \% \mathrm{w} / \mathrm{v}$ and heatdenatured salmon sperm DNA $100 \mu \mathrm{g} / \mathrm{ml}$. Hybridisation with ${ }^{32} \mathrm{P}$ dCTP-labelled, oligonucleotide-primed EcoRI g fragment ${ }^{22}$ of $\mathrm{HSV}-1$ was performed overnight at $68^{\circ} \mathrm{C}$ in fresh pre-hybridisation buffer. Blots were washed in a solution of $0.1 \times \mathrm{SSC}$ and SDS $0.1 \% \mathrm{w} / \mathrm{v}$ for $1 \mathrm{~h}$ at $68^{\circ} \mathrm{C}$, and rinsed several times in the same solution pre-heated to $68^{\circ} \mathrm{C}$ before autoradiography.

Restriction digestion of amplified DNA was performed by adding 10 units of either HpaII or Taq1 to $10-\mu \mathrm{l}$ samples of PCR product and incubating for 3$4 \mathrm{~h}$ at $37^{\circ} \mathrm{C}$ ( HpaII) or $65^{\circ} \mathrm{C}$ (Taq 1$)$. The digested DNA was electrophoresed on agarose $2 \%$ gels, containing ethidium bromide $1 \mu \mathrm{g} / \mathrm{ml}$, and visualised under UV light.

\section{Radioimmunoassay}

The wells of microtitration plates (Dynatech, Billingshurst, Sussex) were coated with $50 \mu$ l of HSV1 (MacIntyre strain) antigen (reconstituted from lyophilised HSV-1 infected Vero cells (PHLS, 61 Colindale Avenue, London) and diluted 1 in 20 in PBS, or control, non-infected Vero-cell antigen, and incubated overnight at room temperature. Unbound antigen was decanted and the wells were washed five times with PBS, and then incubated with $100 \mu \mathrm{l}$ of BSA $0.5 \%$ in PBS (PBS/BSA) for $1 \mathrm{~h}$ at $37^{\circ} \mathrm{C}$ to prevent further non-specific binding.

The blocking buffer was decanted, and $50 \mu \mathrm{l}$ of serum or plasma sample, diluted in PBS/BSA containing polyoxyethylene-sorbiton monolaurate (Tween 
20), $0.05 \%$, was added to wells in triplicate and incubated for $1 \mathrm{~h}$ at $37^{\circ} \mathrm{C}$. After five washes with PBS the wells were incubated for a further hour at $37^{\circ} \mathrm{C}$ with $50 \mu \mathrm{l}(>50000 \mathrm{cpm})$ of ${ }^{125} \mathrm{I}$-radiolabelled goat anti-human IgG (Tago, Burlingame, CA 94010, USA) diluted in PBS/BSA/Tween 20. The wells were washed five times with PBS and air-dried, and the amount of bound ${ }^{125}$ I-radiolabel was counted on a gamma counter.

The results were expressed as the percentage of bound radioactivity. Values greater than the mean plus two standard deviations of the radioactivity bound to the control Vero-cell antigen were taken to be seropositive.

\section{Results}

\section{Polymerase chain reaction studies}

The amplified DNA yielded a 211-bp band visible on ethidium bromide-stained gels under UV light (fig. 1), as well as on Southern blots after hybridisation with a labelled $E c o R 1 \mathrm{~g}$ probe. All the 211-bp bands, analysed by restriction endonuclease digestion yielded the expected 126-bp and 85-bp fragments when digested with $T a q 1$, and 93-bp, 65-bp and 56-bp fragments when digested with $\mathrm{HpaII}$ (fig. 2).

From the patients with BS, $16(50 \%)$ out of 32 DNA preparations from the circulating mononuclear cells showed the 211-bp band (table II). This compared with only three $(13.6 \%)$ out of 22 preparations from healthy controls $\left(\chi^{2}=6.05, \mathrm{p}<0.02\right)$ and five $(16.7 \%)$ out of 30 preparations from patients with recurrent oral ulcers $\left(\chi^{2}=6 \cdot 26, p<0.02\right)$. However, preparations from five $(41.7 \%)$ of the 12 patients with recurrent herpes labialis showed a positive PCR result, a proportion not significantly different from that of the patients with BS, or of the healthy controls $\left(\chi^{2}=2 \cdot 01\right)$. Of the PCR-positive BS patients, $17.6 \%$ were also known to suffer from recurrent herpes labialis, a percentage not significantly different from the $20 \%$ of PCR-negative BS patients with a history of recurrent herpes labialis. Analysis of the four clinical types of

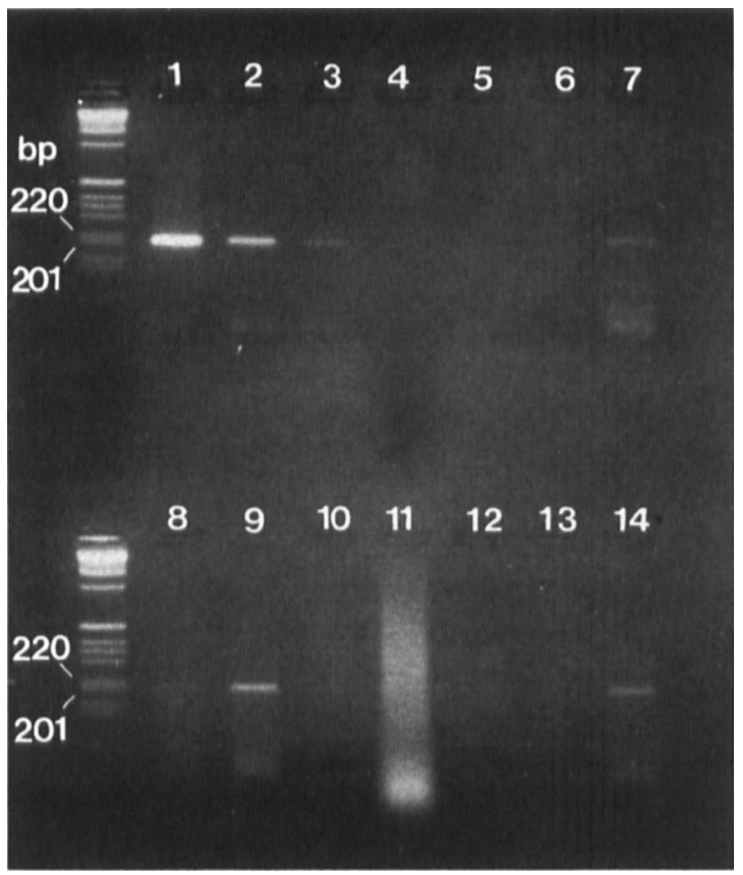

Fig. 1. Electrophoresis of amplified DNA showing the 211-bp amplified band run on agarose $2 \%$ gel, stained with ethidium bromide and viewed under UV light. Lanes 1-3, positive controls; 4 , negative control; 5-14, patient samples (positive samples in lanes $7,8,9,10,14)$.

BS showed little difference in their PCR results $(45 \cdot 4$ $66.6 \%$ ) but there were relatively few muco-cutaneous and neurological patients in the study (table II). Of the five patients with recurrent oral ulcers who showed positive PCR results, three had major aphthous ulcers and two had herpetiform ulcers (table II).

There was no significant correlation of the PCR results with histocompatibility types HLA B51 or DR7. Two (18.2\%) out of 11 PCR-positive BS patients were positive for HLA B51, and three $(37.5 \%)$ out of eight for DR7, compared with two $(22 \cdot 2 \%)$ out of nine patients and two $(33.3 \%)$ out of six patients, respectively, who were PCR-negative.

Examination of DNA extracted from the biopsy material showed only three positive results out of 21 samples examined by PCR--two out of 11 patients

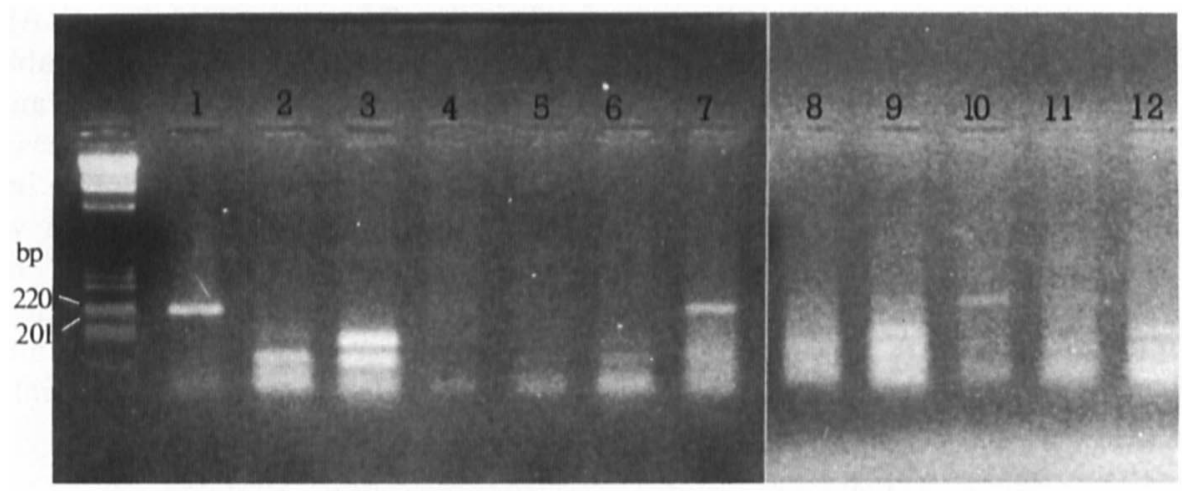

Fig. 2. Electrophoresis of restriction endonuclease digested DNA showing cut and uncut samples run on agarose $2 \%$ gel, stained with ethidium bromide and viewed under UV light. Lanes $1,4,7$ and 10 , uncut 211 -bp samples; $2,5,8$ and 11 , samples cut with $H$ paII; $3,6,9$ and 12, samples cut with Taql. 
Table II. Proportion of patients with HSV-1 211-bp bands detected by PCR amplification

\begin{tabular}{|c|c|c|c|c|}
\hline \multirow{2}{*}{ Diagnosis } & \multirow{2}{*}{$\begin{array}{l}\text { Number of } \\
\text { patients }\end{array}$} & \multirow{2}{*}{$\begin{array}{l}\text { Number }(\%) \\
\text { positive }\end{array}$} & \multicolumn{2}{|c|}{ Significance } \\
\hline & & & $\chi^{2 *}$ & $p$ value \\
\hline $\begin{array}{l}\text { BS } \\
\text { mucocutaneous type } \\
\text { arthritic type } \\
\text { ocular type } \\
\text { neurological type }\end{array}$ & $\begin{array}{r}32 \\
2 \\
12 \\
12 \\
6\end{array}$ & $\begin{array}{l}16(50 \cdot 0) \\
1(50 \cdot 0) \\
5(41 \cdot 7) \\
7(58 \cdot 3) \\
3(50 \cdot 0)\end{array}$ & $\begin{array}{l}6 \cdot 05 \\
0 \cdot 11 \\
2 \cdot 01 \\
5 \cdot 47 \\
1 \cdot 86\end{array}$ & $\begin{array}{c}<0.02 \\
\text { NS } \\
\text { NS } \\
<0.02 \\
\text { NS }\end{array}$ \\
\hline $\begin{array}{l}\text { Recurrent oral ulcers } \\
\text { minor aphthous ulcers } \\
\text { major aphthous ulcers } \\
\text { herpetiform ulcers }\end{array}$ & $\begin{array}{r}30 \\
11 \\
10 \\
9\end{array}$ & $\begin{array}{l}5(16 \cdot 7) \\
0(0) \\
3(30 \cdot 0) \\
2(22 \cdot 2)\end{array}$ & $\begin{array}{l}0 \cdot 01 \\
0 \cdot 37 \\
0 \cdot 37 \\
2 \cdot 01\end{array}$ & $\begin{array}{l}\text { NS } \\
\text { NS } \\
\text { NS } \\
\text { NS }\end{array}$ \\
\hline Recurrent herpes labialis & 12 & $5(41 \cdot 7)$ & $2 \cdot 01$ & NS \\
\hline Healthy controls & 22 & $3(13 \cdot 6)$ & & \\
\hline
\end{tabular}

*The $\chi^{2}$ analysis (with Yates's correction) was calculated against the healthy controls. NS $=$ not significant.

with recurrent oral ulcers, and one other patient with severe artefactual ulceration of the lower lip which persisted for over a year. The three patients with BS who were examined gave negative results.

\section{Presence of serum IgG anti-HSV-1 antibodies}

IgG anti-HSV-1 antibodies (table III) were detected in only seven $(31.8 \%)$ out of 22 healthy controls as compared with $19(67.8 \%)$ out of 27 patients with BS $\left(\chi^{2}=5 \cdot 77, \mathrm{p}<0.02\right)$. Anti-HSV-1 antibodies were demonstrated in a high proportion of patients with recurrent oral ulcers $-19(65.5 \%)$ out of $29\left(\chi^{2}=4.42\right.$, $\mathrm{p}<0.05)$-and, as expected, all 11 patients with recurrent herpes labialis possessed antibodies. The frequency of antibodies did not differ significantly among the four clinical types of BS patients. However, while all but one of the patients with minor aphthous or herpetiform ulcers had antibodies, only a third of the patients with major aphthous ulcers gave positive results (table III).

Table III. Proportion of patients with anti-HSV-1 antibodies

\begin{tabular}{|c|c|c|c|c|}
\hline \multirow[b]{2}{*}{ Diagnosis } & \multirow{2}{*}{$\begin{array}{c}\text { Number of } \\
\text { patients }\end{array}$} & \multirow{2}{*}{$\begin{array}{c}\text { Number }(\%) \\
\text { positive }\end{array}$} & \multicolumn{2}{|c|}{ Significance } \\
\hline & & & $\chi^{2 *}$ & $p$ value \\
\hline $\begin{array}{l}\text { BS } \\
\text { arthritic type } \\
\text { ocular type } \\
\text { neurological type }\end{array}$ & $\begin{array}{l}27 \\
11 \\
11 \\
5\end{array}$ & $\begin{array}{l}19(67 \cdot 8) \\
7(63 \cdot 6) \\
8(72 \cdot 7) \\
4(80 \cdot 0)\end{array}$ & $\begin{array}{l}5 \cdot 77 \\
1.88 \\
3.49 \\
0.65\end{array}$ & $\begin{array}{l}<0.02 \\
\text { NS } \\
\text { NS } \\
\text { NS }\end{array}$ \\
\hline $\begin{array}{l}\text { Recurrent oral ulcers } \\
\text { minor aphthous ulcers } \\
\text { major aphthous ulcers } \\
\text { herpetiform ulcers }\end{array}$ & $\begin{array}{l}29 \\
10 \\
12 \\
7\end{array}$ & $\begin{array}{l}19(65 \cdot 5) \\
9(90 \cdot 0) \\
4(33 \cdot 3) \\
6(85 \cdot 7)\end{array}$ & $\begin{array}{l}4 \cdot 42 \\
7 \cdot 13 \\
0 \cdot 01 \\
4 \cdot 25\end{array}$ & $\begin{array}{l}<0.05 \\
<0.01 \\
\text { NS } \\
<0.05\end{array}$ \\
\hline Recurrent herpes labialis & 11 & $11(100)$ & $11 \cdot 14$ & $<0.001$ \\
\hline Healthy controls & 22 & $7(31 \cdot 8)$ & & \\
\hline
\end{tabular}

*The $\chi^{2}$ analysis (with Yates's correction) was calculated against the healthy controls. $\mathbf{N S}=$ not significant.

\section{Discussion}

The polymerase chain reaction detected the presence of $211 \mathrm{bp}$ of the EcoRI g fragment of HSV-1 DNA in peripheral blood lymphocytes from patients with BS. The 211-bp fragment hybridised specifically to a labelled EcoRI g probe, and yielded the expected fragments when digested with Taq1 or HpaII restriction endonucleases. Among the BS patients, $53 \%$ gave positive results for HSV-1 DNA and this is consistent with the findings of Eglin et al $^{17}{ }^{17}$ ( $50 \%$ of BS patients positive) and Bonass et al. ${ }^{18}$ ( $41 \%$ positive). The former detected viral DNA in $80 \%$ of ocular and arthritic type patients, but in only $20 \%$ of mucocutaneous and neurological type patients. In the present study, there were no significant differences among the four groups $(45-64 \%)$, although the numbers of muco-cutaneous and neurological type patients were small. In both investigations, a part of the HSV1 genome was detected in circulating lymphocytes, but there were differences in the proportions of those with the HSV-1 genome in the major and minor aphthous ulcer groups.

Despite the evidence for an association of HSV-1 with BS, ${ }^{12-18}$ the virus has not been isolated from patients. $^{9-11}$ This could be due to the viral DNA being present in small selected fragments, which may or may not be integrated into the host genome, rather than as the intact viral genome found in latently infected ganglia. ${ }^{23-25}$ This could explain why we were unable to detect consistently HSV-1 DNA on Southern blots, despite dot blots being positive when hybridised with a BamHI n probe (unpublished data).

Small fragments of viral DNA in the nuclei of circulating peripheral blood lymphocytes could interfere with the transcription of genomic DNA, resulting in the absence of host cell transcripts, or the production of modified transcripts. It is unlikely that the presence of these fragments could lead to the production of specific viral mRNAs or immediate early DNAbinding proteins, such as infected cell polypeptide 4 (ICP4), which are found in latently infected ganglia $^{26-29}$ and which are expressed as part of a coordinated and well-regulated cascade ${ }^{30}$ The presence in peripheral blood lymphocytes of HSV-1 DNA could affect $T$ cell immunoregulation. ${ }^{31}$ Although the frequency of anti-HSV-1 antibodies (table III) and HSV1 immune complexes ${ }^{16}$ are significantly increased in BS, the T-cell proliferative responses are impaired. ${ }^{15}$ These results argue in favour of an impairment of Tcell immunoregulation, associated with the HSV-1 genome, that does not affect $\mathrm{T}$ helper function. However, preliminary experiments have demonstrated the presence of viral DNA in B cells, and both CD4 and CD8 subsets of peripheral blood lymphocytes, as well as in macrophages.

We thank Dr Ian Haliburton, University of Leeds, for the EcoR $1 \mathrm{~g}$ fragment of HSV-1. This work was supported by an Arthritis and Rheumatism Council grant. 


\section{References}

1. Lehner T, Batchelor JR. Classification and an immunogenetic basis of Behçet's syndrome. In: Lehner T, Barnes CG (eds) Behçet's syndrome. London, Academic Press. 1979: 1332.

2. Hooks JJ. Possibility of a viral etiology in recurrent aphthous ulcers and Behçet's syndrome. J Oral Pathol 1978; 7 : 353364.

3. Behçet $H$. Über rezidiviernde, aphthose durch ein Virus verursachte Geschwüre am Mund, am Auge und and en Genitalien. Dermat Wchrschr 1937; 105: 1152-1157.

4. Lehner T, Sagebiel RW. Fine structural findings in recurrent oral ulceration. Brit Dent $J 1966 ; 121$ : 454-456.

5. Lehner T. Pathology of recurrent oral ulceration and oral ulceration in Behçet's syndrome: Light, electron and fluorescence microscopy. J Pathol 1969; 97: 481-494.

6. Sezer N. Further investigations on the virus of Behçet's disease. Am J Ophthalmol 1956; 41: 41-55.

7. Evans AD, Pallis CA, Spillane JD. Involvement of the nervous system in Behçet's syndrome. Lancet 1957; 2: 349-353.

8. Mortada A, Imam IZE. Virus aetiology of Behçet's syndrome. Brit J Ophthal $1964 ; 48: 250-259$.

9. Dowling GB. Discussion on Behçet's disease. Proc R Soc Med $1961 ; 54: 101-104$

10. Denman AM, Fialkow PJ, Pelton BK, Salo AC, Appleford DJ. Attempts to establish a viral aetiology for Behçet's syndrome. In: Lehner T, Barnes CG (eds) Behçet's syndrome. London, Academic Press. 1979: 91-105.

11. Poulter LW, Lehner T. Immunohistology of oral lesions from patients with recurrent oral ulcers and Behçet's syndrome. Clin Exp Immunol 1989; 78: 189-195.

12. Denman AM, Fialkow PJ, Pelton BK, Salo AC, Appleford DJ, Gilchrist C. Lymphocyte abnormalities in Behçet's syndrome. Clin Exp Immunol 1980; 42: 175-185.

13. Hollingworth P, Hylton W, Pelton BK, Denman AM. Effects of immunosuppression on herpes simplex virus growth in lymphocytes of patients with connective tissue diseases. Ann Rheum Dis 1983; 42: 264-69.

14. Bacon TH, Özbakir F, Elms CA, Denman AM. Interferon- $\gamma$ production by peripheral blood mononuclear cells from patients with Behçet's syndrome. Clin Exp Immunol 1984; 57: $541-547$.

15. Young C, Lehner T, Barnes CG. CD4 and CD8 cell responses to herpes simplex virus in Behçet's disease. Clin Exp Immunol 1988; 73: 6-10.

16. Hussain L, Ward RG, Barnes CG, Lehner T. Antibodies to herpes simplex virus in polyethylene glycol precipitable complexes and in sera from patients with Behçet's disease. In : Lehner T, Barnes CG (eds) Recent advances in Behçet's disease. International Congress and Symposium Series Royal Society of Medicine 1986; 103: 73-77.

17. Eglin RP, Lehner T, Subak-Sharpe JH. Detection of RNA complimentary to herpes-simplex virus in mononuclear cells from patients with Behçet's syndrome and recurrent oral ulcers. Lancet 1982; 2: 1356-1361.

18. Bonass WA, Bird-Stewart JA, Chamberlain MA, Halliburton IW. Molecular studies in Behçet's syndrome In: Lehner T, Barnes CG, (eds) Recent advances in Behçet's disease. International Congress and Symposium Series Royal Society of Medicine, 1986; 103: 37-41.

19. Lehner T. Recurrent aphthous ulceration and autoimmunity. Lancet 1964; 2: 1154-1155.

20. McGeoch DJ, Dolan A, Frame MC. DNA sequence of the region in the genome of herpes simplex virus type 1 containing the exonuclease gene and neighbouring genes. Nucl Acids Res 1986; 14 : 3435-3448.

21. Saiki RK, Scharf S, Faloona $F$ et al. Enzymatic amplification of $\beta$-globin genomic sequences and restriction site analysis for diagnosis of sickle cell anemia. Science 1985; 230: $1350-1354$.

22. Feinberg AP, Vogelstein B. A technique for radiolabeling DNA restriction endonuclease fragments to high specific activity. Anal Biochem 1984; 137: 266-267.

23. Rock DL, Fraser NW. Detection of HSV-1 genome in central nervous system of latently infected mice. Nature $1983 ; 302$ : 523-525.

24. Wigdahl B, Scheck AC, Ziegler RJ, De Clercq E, Rapp F. Analysis of the herpes simplex virus genome during in vitro latency in human diploid fibroblasts and rat sensory neurons. J Virol 1984; 49: 205-213.

25. Efstathiou S, Minson AC, Field HJ, Anderson JR, Wildy P. Detection of herpes simplex virus-specific DNA sequences in latently infected mice and humans. J Virol 1986; 57 : 446-455.

26. Green MT, Courtney RJ, Dunkel EC. Detection of an immediate early herpes simplex virus type 1 polypeptide in trigeminal ganglia from latently infected animals. Infect Immunol 1981; 34: 987-992.

27. Spivack JG, Fraser NW. Detection of herpes simplex virus type 1 transcripts during latent infection in mice. J Virol 1987; 61 : 3841-3847.

28. Rock DL, Nesburn AB, Ghiasi $\mathrm{H}$ et al. Detection of latencyrelated viral RNAs in trigeminal ganglia of rabbits latently infected with herpes simplex virus type $1 . J$ Virol 1987 ; 61 : $3820-3826$.

29. Deatly AM, Spivack JG, Lavi E, Fraser NW. RNA from an immediate early region of the type 1 herpes simplex virus genome is present in the trigeminal ganglia of latently infected mice. Proc Natl Acad Sci USA 1987; 84: 32043208.

30. Honess RW, Roizman B. Regulation of herpesvirus macromolecular synthesis. 1: Cascade regulation of the synthesis of three groups of viral proteins. J Virol 1974; 14: 8-19.

31. Lehner $\mathbf{T}$. The role of a disorder in immunoregulation, associated with herpes simplex virus type 1 in Behçet's disease. In: Lehner T, Barnes CG (eds) Recent advances in Behcet's disease. Royal Society of Medicine, International Congress and Symposium Series 1986; 103: 31-36. 